\title{
Nitrate concentration and nitrate reductase activity in the leaves of three legumes and three cereals*
}

\author{
BY P. T. C. NAMBIAR, T. J. REGO AND B. SRINIVASA RAO \\ Intemational Crops Research Institute for the Semi-Arid Tropics \\ (ICRISAT), Patonchenu, A.P., S02 324. India
}

(Acceped 23 December 1987)

\begin{abstract}
SUMMARY
Nitrate concentration and nitrate reductase activity (NRA) were studied in the leaves of soybean (Glycine max), groundnut (Arachis hypogaea) and cowpea (Vigna unswiculata) and sorghum (Sorghwm bicolor), pearl millet (Pennisetum americanum) and maize (Zea mays) at three nitrogen fertiliser levels in two field experiments.

Higher nitrate concentrations were detected in the leaves of groundnut, cowpea and peari millet than in sorghum and maize. Nitrate content in the leaves and leaf NRA were not related acroas crop species, nor was a generalised pattern of leaf NRA and leaf nitrate observed within legumes or within cereals. Nitrogen application realted in higher nitrate availability in the leaves, with varied leaf Nu.
\end{abstract}

\section{INTEODUCTION}

The reduction of aitrate to nitrite, catalysed by the enzyme nitrate reductase (EC 16.6.1, NADH : aitrate oxidoreductase), is believed to be the rate-limiting step in mineral nitrogen utiliation in plants and is an inducible enzyme by substrate nitrate in the majority of plants investigated (Beevers \& Hageman, 1969; Srivastava, 1980). In come plants, however, both inducible and conatitutive enzymes are detected, for example in coybean (Neleon, Streit \& Harper, 1956). Although nitrate reductase is detected in most plant parts, including roots, moet of the nitrate is reduced in the leaves when exogenous nitrate is taken up (Beevers \& Hageman, 1969; Goodman, 1979). We have earlier reported (Nambiar, Rego \& Srinivasa Noo, 1986) that groundnut and sorghum differ in leaf nitrate reductase activity and leaf nitrate concentration. The concentration of nitrate in leaves was lower in corghum than in rroundnut, while lear NRA was higher in sorghum than in groundnut. The present inveatieation examines whether these difierences bold true for other cereals and legumes.

\section{matenials aND METHOD}

Phents. The legames teated were coybean (Glycine max L.) (resotype IS 7244), cowpea (Vima unguculase (L.) Watp) (EC 6216), eroundnut (Arachis hypozaed L.) (nodulating ICGS II) and a son-botabtins proundnut (Non-nod). The cereals teated were mnize (Zea mays L.)

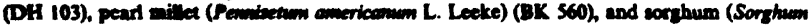
boolor L. Moench) (CSH 8k). Groundmut and compen were nodulated well by exieting thisobia, while soybean did not form nodules without incoulation. Hence, coybean was tioted with and withon Ahtodhm (train TAL 102) incculation. The experiments were coaducted 
on Alfied felds at ICRISAT Center, near Hyderabad, Indie, as deacribed previoualy (Nambiar at al, 1996) and ammaried below

Expt I. The seeds were sown during the post-rainy season on 29 November 1985 on raised beds, $1.5 \mathrm{~m}$ wide, with three rows per plot for cereals and four for legumes. Plant spacing within the row was $20 \mathrm{~cm}$. All crops were fertilised with three levels of nitrogen $(0,100,200 \mathrm{~kg}$ $\mathrm{N}$ ha-1 as urea), applied in four equal applications, 11, 31, 52, 73 days after sowing (DAS). Leaf samples for nitrate reductase activity (NRA) and nitrate estimations were collected at 66. 80, 94, 109 and 129 DAS. Owing to poor seed germination, observations on the pearl millet crop were not made in this season.

Expt 2. The same crops were sown during the rainy season on 24 June 1986 on four ridges $60 \mathrm{~cm}$ apart on a plot $4 \mathrm{~m}$ long. All crops were fertilised at three levels of nitrogen $(0,100$, $200 \mathrm{~kg} \mathrm{~N}^{-1}$ as urea) applied in four equal applications (15, 36, 55, 76 DAS). Leaf samples for NRA and nitrate estimations were collected at 35, 56, 70, 84, 98 DAS. Owing to damage by shoot fly, observations on sorghum were not made in this season.

Table 1. Effect of nitrogen application on leaf nitrate concentration of crop species during the 1985-86 post-rainy season

$\overbrace{0 \quad \log _{\text {Nitrate content }}^{200} \mathrm{NO}_{3} \text { 'dry lean }}^{\text {Nitrogen applied (ks has }}$

66 DAS (Days after sowing)

$\begin{array}{lrrrr}\text { 1. Groundnut (Non-nod) } & \bullet 2032(3.25) & 2896(3.11) & 5290(3.64) & 3406(3.33) \\ \text { 2. Groundaut (ICGS II } & 2497(3.39) & 3239(3.16) & 3646(3.15) & 3124(3.23) \\ \text { 3. Cowped } & 1837(3.20) & 3958(3.00) & 6931(3.64) & 4242(3.28) \\ \text { 4. Soybean (Uninoc.) } & 519(2.60) & 359(1.97) & 1184(2.35) & 687(2.31) \\ \text { 5. Soybean (Inoc.) } & 1002(2.82) & 656(2.43) & 2267(3.28) & 1308(2.85) \\ \text { 6. Maim } & 1074(2.90) & 983(2.10) & 1788(2.50) & 1282(2.50) \\ \text { 7. Sorthum } & 693(2.76) & 518(2.28) & 878(2.30) & 696(2.45)\end{array}$

a. $\pm=(0-1639) ; b=(0-1073) ; c=(0-2839)$.

\section{CO DAS}

\begin{tabular}{|c|c|c|c|c|}
\hline 1. Groundnut (Non-nod) & $293(2 \cdot 18)$ & $1126(2 \cdot 70)$ & 2488 (3.34) & $1303(2 \cdot 74)$ \\
\hline 2. Groundaut (ICGS-11) & $1173(2.97)$ & $2232(3.34)$ & $2926(3.45)$ & $2110(3 \cdot 25)$ \\
\hline 3. Compa & $393(2.31)$ & $1628(3 \cdot 16)$ & $2593(3.37)$ & $1540(2.95)$ \\
\hline 4. Soybean (Uninoc) & $6(1.29)$ & $361(2 \cdot 49)$ & $920(2.57)$ & $448(2 \cdot 12)$ \\
\hline 5. Soybean (lnoc.) & $106(1.72)$ & $740(2.79)$ & $1124(2.72)$ & $657(2.41)$ \\
\hline 6. Maire & $63(1.28)$ & $321(2-47)$ & $757(2 \cdot 79)$ & $380(2 \cdot 18)$ \\
\hline 7. Sorghum & $103(1.63)$ & $224(2 \cdot 34)$ & $685(2.71)$ & $337(2 \cdot 23)$ \\
\hline
\end{tabular}

8. $\pm a-(0.1242) . b=(0.613) ; c-(0.2150)$

\section{DAS}

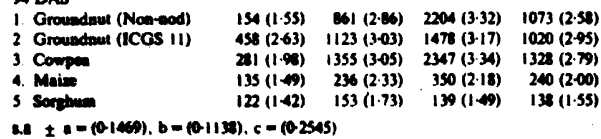

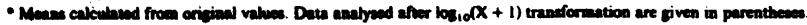

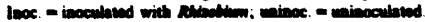

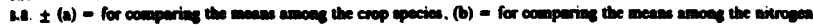

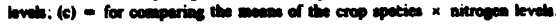


Table 2. Effect of nitrogen application on leaf nitrate concentration of crop species during the 1986 rainy season

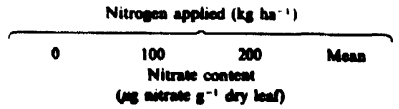

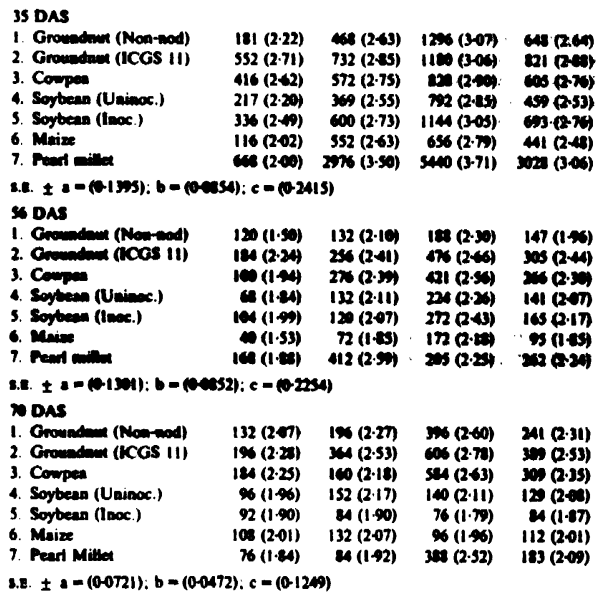

For details Table I

Leaf NRA. Discs of $8 \mathrm{~mm}$ diameter were cut from each leaf and incubated in adium phosphate buffer. (0.1 $\mathrm{m}$ sodium phosphate, $\mathrm{pH} 7.5,5 \%$ n-propanol and $0.02 \mathrm{M} \mathrm{KNO}_{3}$; approximately $2 \mathrm{ml}$ buffer/each disc). The discs were subjected to vacuum infiltration for $2 \mathrm{~min}$ at $1 \times 10^{3} \mathrm{~Pa}$ and incubated at $30^{\circ} \mathrm{C}$ for $30 \mathrm{~min}$. The incubated mixture was filtered through a nitrate-free Whatman No. 1 filter paper and nitrite content was estimated using Szechrome NIT (Hunter, Fahring. Olsen \& Porter, 1982).

Leaf nitrate content. The separated leaves were dried at $60^{\circ} \mathrm{C}$ for $48 \mathrm{~h}$ and finely ground to pass through a $1 \mathrm{~mm}$ sieve. A sample of $0.1 \mathrm{~g}$ leaf powder from the $1985-1986$ peat-rainy samples was mixed with nitrate-free, activated charcoal in a ratio of $1: 2$. The nilute was extracted into $20 \mathrm{ml}$ of distilled water and estimated using Szechrome NAS (Hunter et al., 1982).

A sample of $0.5 \mathrm{~g}$ leaf powder from the 1986 rainy season samples was mixed with vitratefree, activated charcoal in a ratio of $1: 2$ The nitrate was extracted into $30 \mathrm{~mJ}$ of diatilled water and estimated using phenol disulphonic acid (Donald Nason. 1957). 
Table 3. Effect of nitrogen application on leaf NRA of crop spectes during the 198586 postrainy season

Nitrogen applied (k8 ha ')

$\mathbf{0}$

$\begin{array}{ll}100 & 200 \\ \text { Nitrate reductase activity } \\ \left.\text { (nmoles NO; } \mathrm{s}^{-1} \mathrm{~h}^{-1}\right)\end{array}$

C DAS

\begin{tabular}{|c|c|c|c|c|}
\hline Groundnut (Non-nod) & $1067(2.96)$ & $2313(3 \cdot 33)$ & $2152(3.25)$ & $1844(3.18)$ \\
\hline 2. Oroundaut (ICGS 11) & $1401(3 \cdot 10)$ & $1125(300)$ & $1588(3.18)$ & $1371(3 \cdot 10)$ \\
\hline Cowpen & $449(3.62)$ & $5569(3.69)$ & $6278(3.76)$ & $5442(3.69)$ \\
\hline Soybean (Uminoc.) & $867(2 \cdot 87)$ & $3678(3.51)$ & $25 \% 6(3 \cdot 31)$ & $2380(3.23)$ \\
\hline Soybean (Inoc.) & $1144(2.90)$ & $6219(3.59)$ & $5530(3.69)$ & $4298(3.39)$ \\
\hline Maize & $2009(3.27)$ & $3330(3.45)$ & $2998(3.44)$ & $2806(3.39)$ \\
\hline an & $1514(3.07)$ & -176 & 2247 & 13) \\
\hline \multicolumn{5}{|c|}{ e. $\pm a=(0-0525) ; b=(0-0344) ; c=(0.0909)$} \\
\hline \multicolumn{5}{|l|}{ DAS } \\
\hline 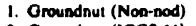 & 382 & $797(2.88)$ & $790(2.89)$ & $656(2.78)$ \\
\hline nit & & & & $(2 \cdot 77)$ \\
\hline ea & 1477 & $2211(3.33)$ & 2561 & $2083(3.28)$ \\
\hline Soybean (Un & 695 & $1834(3.25)$ & 2710 & $1746(3.16)$ \\
\hline Coybeas (Lecc.) & $1200(3.05)$ & $2734(3.38)$ & $2.348(3.36)$ & $2094(3.26)$ \\
\hline & $1568(3 \cdot 18)$ & $(3 \cdot 25)$ & $1759(3.22)$ & $1722(3.22)$ \\
\hline & $1630(3 \cdot 19)$ & $2302(3 \cdot 32)$ & $3050(3.47)$ & $2328(3.33)$ \\
\hline \multicolumn{5}{|l|}{ $\pm a=(0.0262): b=(0.0$} \\
\hline \multicolumn{5}{|l|}{ DAS } \\
\hline C & 316 & $609(2.47)$ & 79 & $573(2 \cdot 38)$ \\
\hline $\cos 1$ & $533(2.69)$ & $736(2.56)$ & $929(2 \cdot 94)$ & $733(2 \cdot 73)$ \\
\hline & $1619(3.18)$ & $2544(3.37)$ & $2995(3.45)$ & $2386(3.33)$ \\
\hline & $1685(3.21)$ & $2210(3.34)$ & $3024(3.46)$ & $2306(3.34)$ \\
\hline & $1677(3.17)$ & $3420(3.52)$ & $2866(3.42)$ & $2654(3.37)$ \\
\hline
\end{tabular}

s. $\pm=-(0.1032), b=(0.0799) ; c=(0.1788)$

For details see Table 1 .

\section{RESULTS}

Data of only the first three samplings are presented. Some of the crop species matured by this time and, in general, results from the later samplings do not contradict those from the earlier dates. In general, application of nitrogen fertiliser increased leaf nitrate and leaf NRA (Tables 1 to 4) although results of all $\mathrm{N}$ level treatments are presented in tables, only mean values of $\mathbf{N}$ treatments are discussed.

Leaf nitrate content. During the post-rainy season, nitrogen application increased leaf nitrate content in all crop spocies (Table 1). Groundnut (nodulating) and cowpea had higher and maize had lower nitrate content at all the three sampling times. Similar results were observed during the rainy season although, in general, nitrate concentrations were lower (Table 2). Very high nitrate levels were detected in pearl millet. especially at 35 DAS.

Leaf NRA. During the post-rainy season the highest leaf NRA was observed in cowpea. Next highest were soybean, maize. Non-nod. sorghum, and nodulating groundnut in that order af 66 DAS (Table 3). Groundnut with $200 \mathrm{~kg} \mathrm{ha}^{-1} \mathrm{~N}$ had only one-fourth the leaf NRA of soybean. During the 1986 rainy seeason inoculated soybean had highest NRA at 35 DAS (Table 4), followed by peart millet. maize and cowpea. Groundnut had the lowest leaf NRA throughout the samplings. 
Table 4. Effect of nitrogen application on leaf NRA of crop species during the 1986 rainy season

Nitrogen applied (ks ha-")

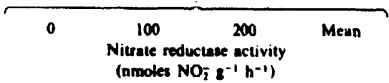

35 DAS

$\begin{array}{lrrrr}\text { 1. Groundnut (Non-nod) } & 620(2.73) & 873(2.92) & 999(2.95) & 830(2.87) \\ \text { 2. Groundnut (ICGS 11) } & 415(2.58) & 768(2.86) & 536(2.69) & 573(2.71) \\ \text { 3. Cowpea } & 651(2.77) & 1127(3.01) & 964(2.90) & 914(2.90) \\ \text { 4. Soybean (Uninoc.) } & 1462(3.05) & 4053(3.51) & 4810(3.54) & 3442(3.37) \\ \text { 5. Soybean (Inoc.) } & 2805(3.20) & 5924(3.58) & 6273(3.63) & 5001(3.47) \\ \text { 6. Maize } & 1008(2.83) & 1621(3.16) & 1512(3.17) & 1580(3.05) \\ \text { 7. Pearl millet } & 1866(2.94) & 2441(3.34) & 2098(225) & 21.35(318)\end{array}$

s.E. $\pm a=(0.0949), b=(0.0581), c=(0.1644)$

S6 DAS

1. Groundnut (Non-nod) $\quad 107(197) \quad 348(2.47) \quad 472(2.60) \quad 3(199(2.34)$

2. Groundnut (ICGS.II) $205(2.28) \quad 341(2.47) \quad 455(2.63) \quad 334(2.46)$

3 Cowpes $\quad 00(2.74) \quad 88.3(2.93) \quad 1162(3.04) \quad 8 \times 4(2.90)$

4. Soybean (Uninoc.) $\quad 76.3(2.70) \quad 1516(3.08) \quad 1287(3.01) \quad 1189(2.03)$

5. Soybean (Inoc.) $\quad 1004(2.85) \quad 1456(3.03) \quad 1530(3.12) \quad 13.30(3.00)$

6. Maize $811(2.87) \quad 1416(3.14) \quad 1553(3.16) \quad 1260(3.06)$

7. Pearl millet $792(2.87) \quad 1336(3.10) \quad 1359(3.0 .3) \quad 1162(3.00)$

s.e. $\pm a=(0.03,35), b=(0.0219), c=(0.0580)$

70 DAS

1 Groundnut (Non-nod) $\quad 104(1.44) \quad 256(1.95) \quad 367$ (2.55) 243 (19\%)

2 Groundnut (ICGS II) $150(176) \quad 183(1.62) \quad 3.34(2.51) \quad 222$ (196)

3 Cowpea

$1169(3.03) \quad 1175(3.06) \quad 1447(3.15) \quad 1264(306)$

4. Soybean (Uninoc) $\quad 490(2.14) \quad 647(2.79) \quad 79 \times(2.88) \quad 647(2.61)$

5 tolinter (Inoc) $\quad 635(2.69) \quad 990(2.97) \quad 1097(3.02) \quad 907(2.89)$

6 Maize $1095(3-01) \quad 948(2.99) \quad 1107(3.04) \quad 1050(3.01)$

7 Pearl millet $911(2.95) \quad 1325(3.12) \quad 1604(3.04) \quad 1280(3.08)$

S.E $\pm a=(0.1126), b=(0.0737), c=(0.1951)$

For details see Tabie 1

\section{DISCUSSION}

In addition to its role as substrate, nitrate in the leaf can induce the enzyme nitrate reductase and also has a stabilising effect on the enzyme (Aslam \& Oaks, 1976). Jones \& Sheard (1975) concluded that only a small fraction of absorbed nitrate is actually involved in enzyme induction. Only small quantities of nitrate are needed $w$ induce the enzyme in cell suspension cultures, and large quantities are needed to stabilise it. In the present study, we did not calculate the $\mathrm{NO}_{3}$ in different metabolic pools and we assumed that $\mathrm{NO}_{3}$ concentration in the leaves was an indication of the $\mathrm{NO}_{3}$ available to the enzyme, even though most of the $\mathrm{NO}_{3}$ is stored in the vacuole (Ferrari, Yoder \& Filner, 1973).

\section{Comparison of leaf nitrate content and leaf NRA among crop species}

Within a given genotype of a crop species, increase in leaf nitrate concentration resulted in increased leaf NRA. In wheat, (Triticum aestivum L.) in vioo data showed that cources of organic carbon were adequate for NRA and that nitrate was the limiting factor for nitrate reductase in situ (Hageman, 1979). However, our studies did not find across the crop apecies a 
definite quantitative relationship between nitrate content in the leaf and leaf NRA. The above comparisons are made from the general trend across the samplings, but since physiological age of these crop species varies one should be cautious in comparing within a sampling date. It should be considered that other difierences like in (i) exploitation by the roots of the soil profile, (ii) rates of $\mathrm{NO}_{3}$ uptake, (iii) root and shoot nitrate reduction and preferential use of other anions to oemoregulate and to maintain leaf turgor, between species and pener exin.

One of the possible explanations for usch large differences across crop species in leaf nitrate content and leaf NRA may be the differences in the affinity of different nitrate reductase for the substrate. This relationship would indicate differences in $\mathrm{Km}$ values (the MichaclisMenton constant), astuming that nitrate avaitable to the enzyme is proportional to leaf nitrate concentration. It is proposed to study the $\mathrm{Km}$ of the enzyme in several crop species. Hageman (1979). from the in ovo asary in wheat, concluded that "in siru, the leaf could assimilate more nitrate into grain protein, if the leaves were supplied with more nitrate, but there is no easy or economical way to maintain bigh levels of aitrate in the leaf blade throughout the vegetative developonent." The data presented here indicate that the above situation may not be true in crop species wch as pearl millet and groundnut where higher vitrate accumuletion does not appareatly result in rapid aitrate incorporation into proteins. Shaner \& Boyer (1976) suceated that, in 14 day-old maize seedlings grown in the grecabouse. nitrate fiux to the leaves from the roots plays a much larger regulatory role then the leaf aitrate consent in coatrolition the level of NRA. . However, it is not known whether this situstion is true for plants grown in the field during the entine growth period. Amoes the legumes there are difierences in aitrate accumulation and leaf NRA. Soybean appears to be a anore efficient utiliser of available nitrate than sroundnut. In soybean only $40-60 \%$ of the cotal plane nitrogen at harvest is accounted for by nitrogen fixation and the reat is derived from mineral $\mathbf{N}$ (Weber, 1966; Deibert, Bijeriego \& Oison, 1979), while in groundnut most of the total plant nitrogen (70 - $90 \%$ ) at harvest is derived from nitrogen fixation (Giller et al., 1987: Yoneyama et al., in preparation). To conclude, we observed no generalised relationship between leaf nitrate content and leaf NRA in the crop species within legumes, or those within cereals.

\section{RBPBRENCES}

ASLAM, M. OAKs A. (1976). Comparative studies on the induction and inactivation of nitrate roductase in corn rooks and leaves. Plant Physiology 57, 572-576.

Eetiviks, L. \& Hobman, R. H. (1969). Nitrate reduction in higher plants. Anmual Review of Plant Physiology 20, 495-522.

DEInERT, E. J., muBribOO, M. OLSON, R. A. (1979). Utilization of ' ' $\mathrm{N}$ fertilizer by nodulating and non. nodulating soybean isolines. Agronomy Jowmal 71.717723.

DONALD, D. J. NAsON, A. (1957). Determinatiop of nitrate and nitrite In Methods in Enzymology Vol. III, p. 981. Eds S. P. Colowick and N. O. Kaplan. Academic Press. New York.

Faranki, T. E. YODER, O. C. FILNES, P. (1973). Anaerobic nitrite production by plant cells and tissues: Evidence for two nitrate pooks. Plent Physiology 51, 423-431

ORLBR, Х. E., NAMELA, P. T. C., SRINTASA RAO, B., DART, P. J. DAY, J. M. (1987). A comperison of nitrogen fixation in genotypes of eroundnut (Arachis hypogaea L.) using ' $\mathrm{N}$-inotope dilution Biblogy and Fertitity of Solls 5, 23-25.

coopun, P. J. (1979). Genetic control of inorganic nitrogen assimilation of crop plants. In Nitrogen Astimilation of Plants, pp. 165-176. Eds E. J. Hewitt and C. V Cuttins. Academic Preas, London. maseuX, R. H. (1979). Integration of nitrogen assimilation in relation to yield. In Nitnogen Assimilation of Plants, pp. $591-611$. Eds E. J. Hewitt and C. V Cutting. Academic Preas, London.

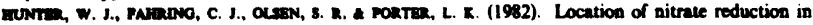
difionent espbean cultivars. Crop Science 22 944-948. 


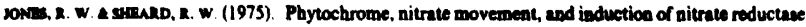
in etiolated pen terminal buds. Plant Physiology 53, 954-959.

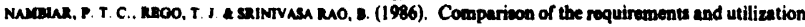
of nitrogen by genotypes of sorghum (Sarginam bicolor (L.) Moench), and nodulatine and nonnodulating groundnut (Arachus hypogaea L.) Field Crops Research 15, 165-179.

NELSON, R. S., STRET, I HARPBR, J E. (1986). Nitrate reductases from Wild-Type and nr,-mutant soybean (Glycine max (L.) Merr.) leaves. Plant Physiology 00, 70-76.

sLNBR, D. L. EOYER, J. S. (1976). Nitrate reductase activity in maize (Zea mays L.) leaves. Plant Physiology 58, 499. 504.

SRivastava, H. 3. (1980). Regulation of nitrate reductase activity in higher plants. Phytochemistry 19 , 725-733.

WEBER, C R. (1966) Nodulating and non-nodulating roybean isolines: Il. Response to applied nitrogen and modified soil conditions. Agronomy Journal S8, 46-49.

(Received 8 Seplember 1987) 